This is in agreement with results obtained by Wareing and Foda ${ }^{3}$, who found that the inhibitor present in Xanthium embryos disappears in high oxygen tensions, before any visible germination changes have taken place. Furthermore, they have been able to obtain an enzyme preparation from the embryos which is capable of destroying the inhibitor in vitro in the presence of oxygen.

By analogy, the evidence presented above for birch seed would justify the assumption that a similar basic mechanism is operative in these seeds also, although, as yet, it has not been possible to demonstrate this.

It is unlikely that the role of light is in the destruction of the inhibitor, since one would not expect any photoperiodic effects if this were true ${ }^{1}$. It is more probable that light is directly involved in the production of a promotive agent which can overcome the effect of the inhibitor.

Department of Botany,

University of Manchester. Aug. 2.

'Black, M., and Wareing, P. F., Physiol. Plant., 8, 300 (1955), ${ }^{2}$ Crocker, W., "The Growth of Plants" (New York, 1948).

s Wareing, P. F., and Foda, H., Nature [p. 908 of this issue].

\section{Glutamic Acid Decarboxylase in Legumes}

SINCE the pioneer researches of Okuniki1,2 and Schales and his associates ${ }^{3-5}$ on glutamic acid decarboxylase, rather scanty data have been made available on amino-acid decarboxylases of plants. Most of the work deals with glutamic acid decarboxylase of higher plants; so it was thought of interest to study the enzyme system in the case of dry seeds of legumes.

The assays were carried out by means of Warburg manometric measurements at $35^{\circ} \mathrm{C}$. Healthy, wellformed seeds were freed of contamination, if any, by thoroughly cleaning them with permanganate solution followed by copious amounts of distilled water. These were dried, finely powdered and stored in sterile bottles in a refrigerator. $3 \mathrm{gm}$. seed powder was extracted with $100 \mathrm{ml}$. $M / 15$ phosphate buffer $\left(p \mathrm{H} \mathrm{5.8)}\right.$ for $\frac{1}{2} \mathrm{hr}$. at room temperature $\left(28^{\circ} \mathrm{C}\right.$. $)$. The extract was then passed through muslin and the activity of $4.0 \mathrm{ml}$. suspension was determined.

Of the leguminous seeds investigated, field bean appears to be the richest source of glutamic acid decarboxylase and is being used for the preparation and purification of this enzyme. In this bean, the product of decarboxylation was identified as $\gamma$-aminobutyric acid by paper chromatography. Field bean extract lost its activity on dialysis at $4^{\circ} \mathrm{C}$. for $18 \mathrm{hr}$.,

Table 1

\begin{tabular}{|c|c|c|}
\hline Seed & Botanical name & $\begin{array}{c}\text { Activity } \\
\text { c.mm. } \\
\mathrm{CO}_{2} / 20 \mathrm{~min} . / \\
\text { gm. dry seed }\end{array}$ \\
\hline $\begin{array}{l}\text { Field bean } \\
\text { Double bean } \\
\text { Aconite bean } \\
\text { Cow-pea } \\
\text { Green pea } \\
\text { Black pea } \\
\text { Bengal gram } \\
\text { Green gram } \\
\text { Lentil } \\
\text { Red gram }\end{array}$ & $\begin{array}{l}\text { Dolichos lablab, L. } \\
\text { Vicia faba, Möench } \\
\text { Phaseolus aconitifolius, Jacquin } \\
\text { Vigna catjang. Walp. } \\
\text { Pisum sativum, L. } \\
\text { (Indian variety) } \\
\text { Pisum arvense, L. } \\
\text { (Black variety) } \\
\text { Cicer arietinum, L. } \\
\text { Phaseolus aureus, Roxb. } \\
\text { Lens esculenta, Möench } \\
\text { Cajanus indicus, Spreng. }\end{array}$ & $\begin{array}{c}1,180 \\
97 \cdot 54 \\
95 \cdot 72 \\
306 \cdot 1 \\
30 \cdot 24 \\
28 \cdot 30 \\
95 \cdot 96 \\
346 \cdot 9 \\
\text { nil } \\
58 \cdot 2\end{array}$ \\
\hline
\end{tabular}

which could be partially restored by addition of pyridoxal-5-phosphate. Addition of pyridoxal phosphate to the original extract was also found to enhance its activity considerably. This activating influence of pyridoxal phosphate suggests that the same is the coenzyme of the decarboxylase.

Further studies on the purification of the field bean glutamic acid decarboxylase are in progress. The leguminous seeds are also being tested for other amino-acid decarboxylases.

We are thankful to Dr. K. V. Giri for the gift of $\gamma$-amino-butyric acid and to the Government of India for the award of a senior research scholarship to one of us (L. K.).

LEELA KULKarni

Department of Biochemistry, KaMaLA SoHonie

Institute of Science,

Bombay 1.

June 30.

' Okuniki, K., Bot. Mag., Tokyo, 51, 270 (1937).

2 Okuniki, K., Acta Phytochim., Japan, 13, 155 (1943).

${ }^{3}$ Schales, O., Mims, V., and Schales, S. S., Arch. Biochem., 10, 455 (1946).

- Schales, O., and Schales, S. S., Arch. Biochem., 11, 155 (1946).

'Schales, O., and Schales, S. S., Arch. Biochem., 11, 445 (1946).

\section{Endosperm and Seed of Wolffia}

SINCE the days of Hegelmaier ${ }^{1}$ there has been little or no work on the embryology and seed structure of Wolffia. Recently ${ }^{2}$, I pointed out the probability of a cellular endosperm in this genus. Later, the occurrence of a cellular endosperm was also confirmed in Lemna paucicostata ${ }^{3}$, which contradicts Lawalrée's ${ }^{4}$ report of a helobial endosperm in $L$. minor.

Abundant flowering material of Wolffia microscopica, available at Delhi, has enabled me to make further observations on the endosperm and seed structure of this plant. The first division of the primary endosperm nucleus is followed by a transverse wall resulting in the formation of a micropylar and a slightly smaller chalazal chamber (Fig. 1). At this stage the zygote is still undivided. Next, there is a transverse division in the chalazal and a vertical division in the micropylar chamber (Fig. 2); meanwhile, the zygote has divided to form the 2-celled proembryo. No free nuclear divisions occur at any time.

An interesting point concerning the structure of the mature seed is that the inner integument is completely crushed except at the micropylar end, where its apical portion forms the so-called operculum. The outer integument persists but comprises only a couple of layers, of which the outer develops reticulate thickenings.

Most of the endosperm is consumed ; only one layer remains and surrounds the embryo. The cells are packed with reserve food materials except in the chalazal region.

The embryo presents a striking resemblance to that of Lemna. While still enclosed within the seed, it has already produced the first frond $\left(f_{1}\right)$ as well as its daughter frond $\left(f_{2}\right)$; and even the initials of the granddaughter frond $\left(f_{3}\right)$ are recognizable. Fig. 3 shows a longitudinal section of the mature seed in which the frond has been cut in a plane at right angles to its flat surface. It is attached to the main body of the embryo by a very short pedicel. On one side it is enclosed by the 'suspensor' and on the other by the 'cotyledonary sheath'. Fig. 4 is an adjacent section in which the outline of the daughter frond 